\title{
Teaching Reading Comprehension In EFL Classroom: A Glance At Some Approaches And Activities
}

\section{Livianni Lambe}

\begin{abstract}
English reading educators in English Foreign Language classroom in Indonesian are often mystified how to teach well reading comprehension to their students. This paper will propose about pedagogy of teaching reading comprehension in EFL classroom relating to the activities in reading instruction, comprehension skills focusing on primary and intermediate level , and strategies in teaching reading comprehension in order to become their students as effective readers and to improve their students' reading comprehension suitable with students' English reading proficiency.

Key words: reading comprehension, activities in reading, primary, intermediate level, strategies.
\end{abstract}

\section{INTRODUCTION}

English as a subject has been introduced in Indonesia from 1945 up to present time. The teaching English in Indonesia as a foreign language has been focused on developing the four language skills- reading, writing, speaking, and listening-with various degrees of proficiency.

Reading, one of language skills, can be classified into initial reading and reading comprehension. In teaching reading when the language is foreign to the student in Indonesia is included in teaching of reading comprehension (Cahyono \& Widiawati, 2011). Reading comprehension is the ability to draw meaning from the printed page and interpret it appropriately ( Grabe \& Stoller, 2002). In this context, reading comprehension is a 
process of getting information from context and combining disparate elements into a new whole.

English reading educators in EFL classroom are often mystified with how to teach reading comprehension properly to their students. This section will describe pedagogy of reading in English as foreign language. Some topics chosen for the discussion in this section are models of reading process, approaches to teaching reading, process of comprehension, activities in reading instruction, comprehension skills for primary and intermediate level, and strategies to increase comprehension.

\section{MODELS OF READING PROCESS}

There are different models involved in the student's reading process in EFL classroom namely bottom-up, top-down, and interactive model. First, the bottom-up model is reading can be taught after students learn the letters of alphabet, followed by words and phrases (Gunning, 1992 \& Cahyono and Widiawati, 2011). In line with this statement, reading is a linear process by which readers decode a text word by word, linking the words into phrases and then sentences ( Kucer,1987 cited in de Debat, 2006). In other word, a reader starts to process from identifying each word letter-by- letter, each sentence word-byword, and each text sentence-by-sentence (Grabe and Stoller,2002). Bottom-up model is especially suitable for EFL students who feel the English text being read is difficult. Second, the top-down model is reading is not just extracting meaning from a text but a process of connecting information in the text with the knowledge the reader brings to act of 
reading (de Debat, 2006). In other words, readers must have background knowledge and language competence as well as readers' understanding about the cues that are on the text that can activate the content schemata (Cahyono and Mukminatien, 2011). This model emphasizes on comprehension and only partly on the phonic, syntactic and semantic systems of the language ( Dubin and Bycina,1991 cited in Hadi, 2006). At this model, students are going to do guessing the meaning of the words, predicting what the writer might say, recalling previous experience or information, reading for main ideas, etc. This model is quite difficult for beginning EFL students who are still trying hard to combine sound-symbol correspondences of English. The last is interactive model in which combines the two previous models, bottom-up and top-down. Reading in this model involves parallel processing of information from print and information from background knowledge. Recognition ( by decoding letters, words, and sentences to formulate the meaning of the text) and comprehension of printed words and ideas are the result of using both types of information (Vacca,et al., 1991).

\section{APPROCHES TO TEACHING READING}

The range of approach to teaching reading in classroom may include several aspects within the skills to whole language instructional continuum. A major approach should meet two basic criteria: observable in actual classroom and derived from a theoretical base that is top-down, bottom-up, or interactive. Adhering to these criteria, there are four major approaches to teaching of reading: prescriptive approach, basal reading, language experience, and literature-based (Vacca, et al., 1991). 


\section{Prescriptive Approach}

Prescriptive approach is a kind of individualized instruction which is often favored by teachers who devote large chunks of the reading period to work on phonics. They focus on sound-letter relationship instruction. This approach of teaching reading has come to mean two very different approaches to teachers. One type is associated with bottom-up model. The heavy emphasis is place on prescribing linguistic and other sequential skills. Another type is associated with top-down model. The heavy emphasis is placed on personalizing instruction through literature (Vacca,et al.,1991).

\section{Basal Reading Approach}

Basal reading is a kind of approach occupying the central and broadest position on the reading instructional continuum. This approach uses basal readers to teaching reading. The basal reader series are most widely used materials for teaching reading. They help students become ready for reading and provide them for development and practice in reading (Burns, et al.,1996). Basal reading program comes to the closest to an eclectic approach. That is, within the basal reading program itself some elements of the others approaches are incorporated. Yet basal reading programs, built on scope and sequence foundations (skills, levels, and vocabulary), traditionally have been associated with bottom-up model. This association has been modified over the years with the addition of language experience and literature activities (Vacca,et al.,1991).

\section{Language Experience Approach}


Language Experience approach needs students to experience reading as rewarding and successful process. This approach interrelates the different language arts and uses students' experience as the basis for reading materials. Because the texts or stories used in this approach are developed by the students such as writing stories about field trip, personal experience outside school, questions to be answered, or imaginative stories or poems, etc. This approach helps them to visualize reading a "talk written down" and offers good opportunities for developing the concepts of writing, word, and sentence (Burns, et al., 1996) However, it is difficult to assemble an adequate supply of literature for the wide range of abilities found in every classroom, especially if some of the students are not proficient in English. This approach is tied closely to interactive or top-down model of reading. It is considered a kind of beginning reading approach although strategies of teaching are often connected to writing process (Vacca, et al., 1991).

\section{Literature-Based Approach}

Literature -Based approach is also named a whole language approach in which students engage in reading for enjoyment and for the purpose of locating information, rather than in order to earn good grade. The foundation of a literature-based program must be trade books that books are not written primarily for instructional purposes (Burns,et al.,1996). Vacca,et all (1991) admit that literature-based approach is an approach that the teacher uses to provide individual students interest and enjoyment. In this approach, teacher encourage their students to personally select books that they want to read and the share and 
compare the plots, themes, and character of books they have read (Hilbert, 1993 cited in Burns,et al.,1996). Top-down and interactive models are appropriate to this approach.

\section{PROCESS OF COMPREHENSION}

Comprehension is a cognitive process involving three major factors: the reader, the text, and the context in which the text is read (Gunning, 1992). In other word, comprehension is a process of using prior experiences and writer's cues to construct an understanding of a written text that is relevant to the individual reader who is reading for specific purposes in particular situation (Roe,et al,.1995). Based on the statement above, the process comprehension in reading consists of 3 elements namely reader's prior experiences to understand the message in reading relates to schema theory, the interaction reader and text associates to metacognitive theory, and the text in facilitating reading links to the text structure theory.

\section{Schema Theory}

Schema theory proposes that when individuals obtain knowledge, they attempt to fit that knowledge into some structure in memory that helps them make sense of that knowledge. It also proposes that individuals break down information into chunks which are stored in the brain for later call (Ajideh,2006). In essence, schemata are reader's concepts, beliefs, expectations, processes - everything from past experiences that are used in making sense of things and actions. (McNeil, 1992). In other words, schemata represent a person's concepts related to objects, places, actions, or events (Burns, et al,.1996). According to this 
theory, readers make use both the text and their background knowledge. The top-down model is influenced by schema theory, which emphasizes the importance of the reader's background knowledge in reading process (Ozek and Civelek,2006) to facilitate reading comprehension (Chia, 2001 cited in Ajideh, 2006). Therefore, efficient readers use both their schemata and specific information to predict the words and ideas they will read and to form hypotheses about the text content; then they read to confirm, discount, and revise their theories. They create expectations about text organization and meaning which increase comprehension (Adam and Collins,1986 cited in Roe,et al.,1995). Students who have many experiences are better to anticipate author's idea and words than students with limited experiences.

\section{Metacognitive Theory}

Metacognition refers to the knowledge and control students have their own thinking and learning activities (Roe,etal.,1995). Carnine,etal.,(1990) also states that metacognition concerned learner's knowledge of and use of their own cognitive resources, which involve behaviors such as predicting, self-questioning, paraphrasing, summarizing, rereading to clarify meaning, and retelling. So, metacognitive theory deals with activities in pre-reading, whilst-reading, and post-reading stages which should go through during independent reading or in reading instruction in order to facilitate comprehension and learning (Cahyono and Widiati,2011). Students who have well-developed metacognitive skills are more likely to be independent readers. 
Research shows that skilled comprehenders are aware of different purposes of reading and of ways of adjusting their own knowledge to the demands of the task; they monitor their comprehension and implement corrective strategies when it fails (Baker and Brown, 1994 cited in Roe,etal,1996). Unskilled readers do not seem to be aware that they have failed to understand material they read (Paris and Myers,1981 cited in Roe,etal,1996). So, students need instructional strategies to develop an awareness of their own cognitive process as well as ways of remedying comprehension failures (Roe,etal,1996).

\section{Text Structure Theory}

According to the theory of text structure, a text has a structure. Meyer (1975 cited in Cahyono and Widiawati,2011) states that the structure of a text resembles a tree structure, where the more general information include the more specific information in the text. Strictly speaking, effective readers are active readers who use a variety of strategies and process to construct text meaning. They understand the components and patterns of text structure such as paragraphs, main ideas, and story grammar.

Research reveals that students who recognize the various patterns of written discourse understand and recall text content better. In addition, researchers report that students who use the author's top-level organizational structure/organizational pattern (the basic structure of the text) as an aid to comprehension tend to perform better on recall, summarization, and other comprehension tasks than do readers who do not use this structure. The organizational 
structures of the text are sequential or chronological order, comparison and contrast, cause and effect, definition or explanation, and enumeration or listing pattern.

\section{ACTIVITIES IN READING INSTRUCTION}

Factors related to the reader, the reading situation, and the text all interact as the students reads in instructional settings. To encourage comprehension of whole selections, teachers usually incorporate pre-reading, during-reading, and post-reading activities in lessons.

\section{Pre-Reading Activities}

Most activities are directed at reader's prior knowledge, especially building and activating reader's schemata before reading. Pre-reading activities are instructional activities carried out before students conduct the real reading activities. In pre-reading activities, activations is concerned with students' background knowledge, objective of reading class, learning activities, and motivating the students (Mason and $\mathrm{Au}, 1990$ ). In this stage, teachers try to activate students' schemata related to the topic of the text, by presenting key words, asking questions related to the topic or explaining briefly the contents of the text.

Pre-reading activities are to tell students purpose of reading and learning and to motivate students. According to Finn (1985 cited in Cahyono and Mukminatien, 2011) the purpose of reading include: (1) getting the students thinking along with the lines of the 
story they are about to read and (2) identifying particular information the students should be alert to or a question the students should keep in mind as they read the selections. In motivating students, teachers can do some ways like using an attractive color scheme, a cartoon, a picture, or some other approaches to gain the attention of the students to the text and showing them what they will be able to do when finishing the reading class.

In pre-reading stage, it is important to establish purpose before reading as pre-reading activities aim to make the learners ready to read. The instruction should involve significant variables within the text that can support comprehension such as vocabularies and how information is organized in the text (Cahyono and Widiawati, 2011).

\section{During-Reading Activities}

During reading activities are instructional activities that are going on while reading activities are happening. Greenwood (1981, cited in Cahyono and Mukminatien, 2011) suggests five activities to do in whilst reading. First, readers identify main idea of the text, through giving a title, selecting the most appropriate title, and identifying topic sentence through skimming. Second, readers find the details in the text, trough scanning the text, and finding specific information. Third, readers follow sequence by relating items in a particular order or process. Fourth, readers infer from text by trying to understand the text using their schemata and experience. Fifth, readers recognize the discourse patterns by applying all their linguistic and non-linguistic knowledge to understand the text holistically. 
In addition, Mealy and Nist (1989 cited in Cahyono and Mukminatien, 2011) suggest questioning techniques and guides as strategies during reading activities. Questioning technique involves prompting the retrieval of prior knowledge, focusing attention on checking literal meaning, inferring and applying comprehension or information, and predicting possible test items. Questions in reading activity are also useful to guide and focus students' attention and performance. The questions also activate students' background knowledge. Finally, predictions at time of reading are useful to get students involved with the text.

In during-reading stage, learners should be helped integrate new information with their existing knowledge and apply it to the new situation. So, teacher should help students read effectively by involving them in an active participation. The learners may also be asked to read independently using specified learning strategy such as reading for significant facts or reading for details (Cahyono and Widiawati, 2011).

\section{Post-Reading Activities}

Post reading activities are instructional activities that the students and teacher do after reading takes place. Tierney and Cunningham (1989 cited in Cahyono and Mukminatien, 2011) point out that post-questions, feedback, and group and whole class discussion are activities that can be done in the phase of post reading. The activities function to check students' comprehension about the text being read. The post-questions after reading class activity are very important since information of both greater and lesser important is learned 
(Mealey and Nist, 1989 cited in Cahyono and Mukminatien, 2011). Beside asking questions, summarizing the contents of the text is also applicable to the students, encouraging students to involve more actively with the text. The result of summary can be used as the basis of determining the students' level of understanding to the text. In the post-reading stage, teachers should provide students with opportunities to synthesize essential information from the text in order to gain an overall understanding of what they have read (Cahyono and Widiawati, 2011).

The activity of post-reading can also be in forms of discussion. Students are asked to discusses the writer's ideas. This discussion can be in a group or whole-class discussion. The discussion may depend on the class size. If the class is big, it will be better to have group discussion. If the class is small, it will be better to have whole class discussion.

\section{COMPREHENSION SKILLS FOR PRIMARY LEVEL}

In this section discusses three primary grade comprehension skills: literal comprehension, sequencing and summarizing through the teaching procedure (Carnine,etal.,1990).

\section{Literal Comprehension}

Literal comprehension involves teaching students to retrieve information stated in a passage. In literal comprehension exercise, the answer is directly stated in passage. The following procedure is designed to introduce literal comprehension items. The procedure 
would be used only if students were unable to work literal items on their own. The teaching procedure consists of (1) teacher asks students to decode the passage until they can do so fluently, (2) teacher explains and tests the students' understanding of the instruction, and (3) teacher asks students to read the first item, asks if they remember the answer, and, if not, directs them to reread the passage until they come to the sentence that contains the answer.

\section{Sequencing}

Sequencing requires ordering several events according to when they occur in a passage. For example, a student reads a passage and then writes numbers in front of several phrases that describe events, writing 1 in front of the event that occurred first, 2 in front of the event that occurred next, etc. The teaching procedure involves (1) students read the passage, (2) for each event, the students underline the words in the passage that coincide with the event, (3) the students number the events underline the passage, beginning with one, and (4) the students then write the numbers in front of the appropriate items in the question. The length of the passage and the number of items to be sequenced should increase gradually. The increases in difficulty occur when the students are able to do the sequence without error.

\section{Summarization}

Summarization not only allows the students to identify the key ideas from a passage but it also reduces the information in a passage to key ideas that students can remember. Summarization involves teaching students to generate or select a sentence that expresses 
main idea. A summary condenses a passage into a few sentences. A sentence summary can be considered a main idea. The teaching procedure includes (1) the teacher tells the students a rule for writing a main idea sentence, (2) the students read the passage, (3) the teacher asks the students to figure out a main idea sentence by naming the person and telling what the person did in all the sentence, (4) the teacher calls on a student to say the sentence. The teacher corrects the students by telling the correct answer, (5) the teacher repeats the same procedure with the remaining passage, (6) the teacher has the students write the main idea sentence for each paragraph (difficult to spell words would be written on the board).

\section{COMPREHENSION SKILLS FOR INTERMEDIATE LEVEL}

In this segment discusses three intermediate level comprehension skills: making inferences based on relationship, comprehending sentences with complicated syntactic structures (i.e., passive voice), and critically reading passages and how to teach them to the students (Carnine,etal.,1990).

\section{Inference}

Inferential questions require knowledge of relationship between two objects or events. Sometimes the relationship is directly stated in a passage or the relationship is not specified that students are expected to know particular relationship or are expected to infer the relationship using the information stated in a passage. When the relationship is stated in the passage, the teaching procedure comprises (1) teacher asks the students to read the entire passage, (2)teacher asks the students to find and to say it, example of the rule "The 
faster you run, the more oxygen you use.”, (3) teacher points out what the information given tells, (4) teacher reminds students of the rule, and (5) asks students why they gave that answer. Then, if the relationship is not directly stated in a passage, the teaching procedure includes (1) teacher asks students to read the entire passage, (2) to teach students to find the stated relationship and the information needed to draw an inference based on the stated relationship, (3) students must learn to translate any relevant information into a form that directly fits the stated relationship, and (4) students must learn to deal with distractors in a passage. When introducing items with distractors, teacher must emphasize the statement that determiners the answer to the item. Whenever students make mistake because of a distractor, the teacher should require the students locate the part of the passage that specifies the stated relationship. The teacher points out that distractor has nothing to do with the stated relationship and does not lead to the correct answer.

\section{Sentence Structure}

During the intermediate grades, sentence syntax becomes increasingly complicated. A great variety of sentence constructions introduced including participle, clauses, sentences containing connectives, passive constructions, numerical and class-inclusive, and pronouns referring to an action or series of actions. In this section focuses on passive voice/ construction only. In the procedure for teaching students to understand passive voice, the teacher asks questions about a pair of minimally different active and passive voice sentences. The format involves the teacher's presenting an active-voice sentence and asking (1) who was acted upon, (2) who did the acting. After each active-voice sentence, the 
teacher presents a passive-voice sentence and asks the same questions. By answering the questions, students will learn to comprehend both active and passive construction.

\section{Critical Reading}

Critically evaluating assertions, arguments, and proposals, whether presented orally or in print, is possibly the most important comprehension skill related to preparing students for their various roles in life. Many personal, professional, and social decisions are based on what we are told by other people. Because faulty arguments and propaganda are so common, critical thinking has a role in almost every important decision we make. The teaching critical reading involves four components skills namely identifying on author's conclusion, discriminating evidence from opinion, determining the trustworthiness of an author, and identifying faulty arguments. The teaching procedure of the components discusses separately

Identifying an Author's Conclusion.

This skill is closely related to selecting a main idea. This skill can be taught through modeling and extensive practice. A teacher models by presenting a passage, identifying the author's conclusion, and listing supporting details from the passage that led to conclusion. Then the teacher tests by presenting a series of passages, asking students to identify the author's conclusion by citing supporting details. The teacher and the students should discuss unacceptable answers by pointing out why they are unacceptable.

\section{Discriminating Evidence from Opinion}


Teaching students to discriminate fact from opinion is done in two stages. In the first stage, all opinion statements include phrases that indicate that an opinion is being given ( I think, I believe, I feel, in my opinion, etc). The teacher might introduce the items by explaining the difference between fact and opinion. When somebody tells you something that actually happened they are telling you a fact and when somebody tells you how they feel about something they are telling you an opinion. The teacher would present the statements asking the students to tell if the statement is one of fact or opinion.

The second stage of procedure introduces more sophisticated items which do not include phrases as "I think" or "I believe". Teaching students to distinguish fact from opinion with this type of statement involves consensus. If, on the one hand, a person says something with which almost everybody who is knowledgeable agrees, the statement is one fact. If it is a statement with which knowledgeable people disagree, the statement is one of opinion.

\section{Determining the Trustworthiness of an Author}

An important aspect of determining author trustworthiness is examining the qualifications of the person stating the argument. The first step in determining the trustworthiness of the author is determining his expertise regarding what he is talking about. A second step involves examining the motives of an author to determine if he has anything to gain by convincing the reader of his position.

Identifying Faulty Arguments 
Three types of fallacious arguments are tradition (It's been done this way in the past, so it should be done this way in the future), improper generalization ( $\mathrm{X}$ is no good, $\mathrm{X}$ is a $\mathrm{Y}$, so $\mathrm{Y}$ is no good), and coincidence or a confusion of causation and correlation ( $\mathrm{S}$ and $\mathrm{Y}$ happened at the same time, so $\mathrm{S}$ must cause $\mathrm{Y}$ ). The teaching procedure is similar for each type of invalid argument. The teacher states a rule about invalid form and presents a series of examples, asking whether the argument in each example is valid. After students have learned the first two forms of invalid conclusions, they receive discrimination practice in determining which form account for an invalid conclusion. In this discrimination exercise the teacher presents a series of examples and asks. The students then have to indicate what invalid argument was used to draw the conclusion. This discrimination of exercise also appears again after the third from invalid argument is introduced; students identify which of three form accounts for an invalid conclusion.

\section{STRATEGIES TO INCREASE COMPREHENSION}

Strategies and activities are introduced to improve students' comprehension. Some of these strategies should be implemented before reading, during reading and after reading. Questions and discussion are essential for increasing comprehension. They are tools that teacher can use to encourage cognitive development (Roe,etal.,1995)

\section{Discussion}

Discussion is important both as a communication skill and as a means for developing higher-order thinking (Alvermann,etal.,1987 cited in Roe,etal.,1995). Discussion offers a 
teaching and learning alternative to the lecture method. In discussion, participants interact as they present multiple points of view and listen to counterarguments. Meanings shared in discussion groups are more than a collection of individual ideas; they are part of new sets of meanings developed as members talk and listen to one another (Pinelli,1984 cited in Roe,etal.,1995).

\section{Question-Answer Relationship}

Use of question-answer relationship (QAR) introduced by Raphael is another questioning strategy to increase comprehension. This procedure focuses on the processes for generating answers to questions and on the relationships between questions and answers. Students are encouraged to think of sources for answers to questions.

\section{K-W-L (Know-want to Know-Learn)}

This strategy encourages activation of prior knowledge as well as stimulation of cognition and metacognition (Ogle,1986 cited in Roe,etal.,1995). Initially, the students brainstorm what they already know about the topic about which they will be reading. Then they write the brainstormed information in the $\mathrm{K}$ (Know) column. As the students work, the teacher should encourage column them to categorize the information and list their categories at the bottom of the colum. The students generate questions about the text which are listed in the W (Want to Know) column. Additional questions may be generated as the students proceed. Finally, information learned from the text is entered in the L (Learn) column. 


\section{Think Alouds}

Thinks aloud are strategies that can be used to demonstrate the comprehension process or specific aspect of it (Roe,etal.,1995). The think-aloud process makes thinking public and gives students a model for the kinds of thinking that a reader may do while reading text (Davey,1983 cited in Roe,etal.,1995). Initially, teachers demonstrate think alouds to class. After observing, students can work in pairs, doing think alouds for one another.

When planning a think aloud, teachers should select passages that contain information requiring clarification, such as contradictions, ambiguities, or words meaning that need clarification. As the teacher reads the passage aloud, students allow silently, listening to ways of thinking through each trouble spot as it is encountered. The teacher may also choose specific instances from a text to demonstrate ways of coping when comprehension breaks down.

\section{Reciprocal Teaching}

In this approach, the teacher models the process and then gradually turns it over to the students while providing feedback and encouragement. This activity may be done with pairs or triads (three students). Reciprocal teaching involves four steps. First, teacher or leader summarizes the paragraph in one sentence. Then teacher asks a higher level questions or two, which a student answer. Any difficult parts are clarified at this time. Then a student predicts what the next paragraph or section will discuss. 


\section{Writing Strategies}

Research shows that writing improves reading comprehension. Writing is a way of understanding because it is a mode of language processing along with listening, speaking, and reading. Writing helps students understand and remember ideas and information. When you ask students to write, you are forcing them to shape and form their response to the textto bring these thoughts to conscious awareness (Blatt and Rosen,1984 cited in Roe,etal.,1995). Some writing strategies relate to improving reading comprehension are language experience writing, RAFT assignment, learning log or content journal, etc.

\section{CONCLUSION}

This chapter has reviewed the essential concept related to reading. Reading involves the interaction between reader and writer. The successful reading comprehension is based on factors within the reader, the text, and the reading context or situation. Students comprehend better when they have some degree of control in the reading situation. In order to teach well in EFL classroom, teacher can determine students' level(primary or intermediate level) in reading class for matching texts to the interest or needs and abilities of the students to create them become effective readers.

Strategic readers use appropriate plan and skills before, during, and after reading. They identify the task, establish purposes and select appropriate strategies for reading situation. Many strategies can be used to help students read content area materials and 
narrative more effectively. Some of them are discussion, question-answer relationship, KW-L, think alouds, reciprocal teaching and writing strategies.

\section{REFERENCES}

Ajideh, Parviz. 2006. Schema-Theory Based Consideration on Pre-Reading Activities in ESP

Textbooks. Asian EFL Online Journal Vol 16 Nov.2006. http://www.asian-efljournal.com/November_2006_Vol16_Art2.pdf

De Debat, Elba Villanueva. 2006. Applying Current Approaches to the Teaching of Reading. English Teaching Forum Number 12006.

Burns, Paul.C.,Roe, Betty.D., \& Ross, Elinor.P. 1996. Teaching Reading in Today's Elementary School. Six Edition. Boston: Houghton Mifflin Company.

Cahyono, Bambang.Y.\& Mukminatien, Nur. 2011. Techniques and Strategies to Enhance English Language Learning. Malang: State University of Malang Press

Cahyono, Bambang.Y.\& Utami,Widiawati. 2011. The Teaching of English as a Foreign Language in Indonesia. Malang:State University of Malang Press

Carnine, Douglas.,Silbert,Jerry.,\& Kameenui, Edward.J. 1990. Direct Instruction Reading. Second Edition. Ohio: Merrill Publishing Company A Bell \& Howel Information Company Columbus.

Gunning, Thomas.G. 1992. Creating Reading Instruction for All Children. Boston: Allyn and

Bacon.

Grabe, William \& Stoller, Fredericka.L. 2002. Teaching and Researching Reading. London:

Pearson Education Limited.

Hadi,Abdul.2006. ReadingBased-Classroom Activities: An Effort Toward the Integration of 
Language Skills in Teaching English as a Foreign Langugae in Indonesia. TEFLIN Journal Vol.17 Number 1 February 2006

Ozek, Yesim \& Civelek, Muharrem. A Study on the Use of Cognitive Reading Strategies by

ELT Students. Asian EFl online Journal Vol.14 August.2006.http://www.asian-efljournal.com/August_2006_Vol14_Art2.pdf

Roe, Betty.D., Stoodt, Barbara.D.,\& Burns,Paul.C. Secondary School Reading Instruction. The Content Areas. Fifth Edition. Boston: Houghtoun Mifflin Company.

Vacca,J.A.L, Vacca,R.T., \& Gove,M.K. 1991. Reading and Learning to Read. Second Edition.

New York: Harper Collins Publisher. 